\title{
KETERSEDIAAN FASILITAS KESEHATAN SEBAGAI TEMPAT PELAYANAN PASIEN COVID-19
}

\author{
Melsya Afifah Anggraeni \\ Institut Ilmu Kesehatan Strada Indonesia \\ melsyafifah06@gmail.com
}

\begin{abstract}
Abstrak
Fasilitas kesehatan atau yang sering diakronimkan faskes adalah istilah umum yang merujuk kepada sarana atau prasarana atau perlengkapan yang diwujudkan dalam bentuk pelayanan yang disenggarakan oleh pemerintah, pemerintah daerah atau swasta bagi masyarakat dengan tujuan untuk menjaga atau meningkatkan kesehatan melalui tindakan prevenrif, kuratif maupun rehabilitatif.

Fasilitas pelayanan kesehatan untuk pasien Covid-19 di terus ditambah seiring dengan semakin bertambahnya kasus Covid-19 di Indonesia. Penambahan tersebut karena berdasarkan laporan rumah sakit rujukan, tingkat keterisian tempat tidur rumah sakit (bed occupancy rate) untuk pasien Covid-19 hampir penuh semua.
\end{abstract}

\section{Kata kunci : fasilitas kesehatan,COVID-19.}

\section{Pendahuluan}

1. Latar Belakang

Fasilitas kesehatan merupakan suatu tempat yang digunakan untuk menyelenggarakan upaya pelayanan kesehatan, baik promotif, preventif, kuratif, maupun rehabilitas yang dilakukan oleh pemerintah, pemerintah daerah dan/atau masyarakat. Fasilitas pelayanan kesehatan dibagi menjadi pelayanan keseahatan tingkat pertama, pelayanan kesehatan tingkat kedua dan pelayanan kesehatan tingkat ketiga. Setiap fasilitas pelayanan kesehatan wajib memberikan akses yang luas bagi kebutuhan penelitian dan pengembangan dibidang kesehatan dan mengirimkan laporan hasil penelitian dan pengembangan kepada pemerintah daerah atau Menteri.

COVID-19 adalah penyakit yang disebabkan oleh virus severe acute respiratory syndrome coronavirus 2 (SARS-CoV-2). COVID-19 dapat menyebabkan gangguan sistem pernapasan, mulai dari gejala yang ringan seperti flu, hingga infeksi paru-paru, seperti neumonia. 
Coronavirus adalah kumpulan virus yang bisa menginfeksi sistem pernapasan. Pada banyak kasus, virus ini hanya menyebabkan infeksi pernapasan ringan, seperti flu. Namun, virus ini juga bisa menyebabkan infeksi pernapasan berat, seperti infeksi paru-paru (pneumonia).

Ketersediaan fasilitas kesehatan untuk pelayanan pasien COVID-19 di Indonesia saat ini perlu ditingkatkan lagi karena, jumlah pasien yang terpapar COVID-19 di Indonesia semakin lam semakin bertambah banyak.

2. Rumusan Masalah

Berdasarkan uraian latar belakang diatas, didapatkan rumusan masalah yaitu "Apakah Ketersediaan Fasilitas Kesehatan Pasien COVID-19 Sudah terpenuhi?"

3. Tujuan

1.) Sebagai penyelenggara Pelayanan Kesehatan yang baik promotif, preventif, kuratif, maupun rehabilitatif.

2.) Sebagai tempat rujukan Pasien yang terpapar COVID-19.

\section{Tinjauan pustaka}

1. Pengertian

Fasilitas kesehatan atau yang sering diakronimkan faskes adalah istilah umum yang merujuk kepada sarana atau prasarana atau perlengkapan yang diwujudkan dalam bentuk pelayanan yang disenggarakan oleh pemerintah, pemerintah daerah atau swasta bagi masyarakat dengan tujuan untuk menjaga atau meningkatkan kesehatan melalui tindakan prevenrif, kuratif maupun rehabilitatif.

Fasilitas kesehatan merupakan suatu tempat yang digunakan untuk menyelenggarakan upaya pelayanan kesehatan, baik promotif, preventif, kuratif, maupun rehabilitas yang dilakukan oleh pemerintah, pemerintah daerah dan/atau masyarakat. Fasilitas pelayanan kesehatan dibagi menjadi pelayanan keseahatan tingkat pertama, pelayanan kesehatan tingkat kedua dan pelayanan kesehatan tingkat ketiga. Setiap fasilitas pelayanan kesehatan wajib memberikan akses yang luas bagi kebutuhan penelitian dan pengembangan dibidang kesehatan dan mengirimkan laporan hasil penelitian dan pengembangan kepada pemerintah daerah atau Menteri.

Penyediaan Fasilitas Pelayanan Kesehatan merupakan tanggung jawab Pemerintah Pusat dan Pemerintah Daerah sesuai dengan ketentuan Undang-Undang Nomor 36 Tahun 2009 tentang Kesehatan yang menyatakan bahwa Pemerintah bertanggung jawab atas ketersediaan Fasilitas Pelayanan Kesehatan bagi masyarakat untuk mencapai derajat kesehatan yang setinggi-tingginya. 
Selanjutnya Undang-Undang Nomor 36 Thun 2009 tentang Kesehatan menyatakan bahwa Pemerintah Daerah dapat menentuan jumlah dan jenis Fasilitas Pelayanan Kesehatan serta pemberian izin beroperasi di Daerahnya dengan mempertimbangkan luas wilayah, kebutuhann kesehatan, jumlah dan persebaran penduduk, pola penyakit, pemanfaatannya, fungsi sosial dan kemampuan dalam memanfaatkan.

COVID-19 adalah penyakit yang disebabkan oleh virus severe acute respiratory syndrome coronavirus 2 (SARS-CoV-2). COVID-19 dapat menyebabkan gangguan sistem pernapasan, mulai dari gejala yang ringan seperti flu, hingga infeksi paru-paru, seperti neumonia.

Coronavirus adalah kumpulan virus yang bisa menginfeksi sistem pernapasan. Pada banyak kasus, virus ini hanya menyebabkan infeksi pernapasan ringan, seperti flu. Namun, virus ini juga bisa menyebabkan infeksi pernapasan berat, seperti infeksi paru-paru (pneumonia). Virus ini dapat menular melalui percikan dahak (dorplet) dari saluran pernapasan, misalnya keika berada diruan tertutup yang ramai dengan sirkulasi udara yang kurang baik atau kontak langsung dengan droplet.

Dalam penanganan COVID-19, Pemerintah saat ini telah menyiapkan segala hal yang dibutuhkan dalam upaya penanganan. Mulai dari tenaga medis, ruang perawatan hingga dukungan penuh dari instansi lembaga baik pemerintah maupun swasta.

Pada Fasilitas kesehatan saat ini pemerintah telah menambahakan tempat isolasi pasien baik untuk gejala ringan atau tanpa gejala. Dukungan lain dari pihak swasta berupa hotel-hotel kelas bintang 2 dan bintang 3. Akan tetapi saat ini pasien yang terpapar COVID-19 terus meningkat setiap harinya sehingga Fasiltas Kesehatan perlu ditingkatkan lagi.

\section{Pembahasan}

Fasilitas kesehatan merupakan merupakan suatu tempat yang digunakan untuk menyelenggarakan upaya pelayanan kesehatan, baik promotif, preventif, kuratif, maupun rehabilitas yang dilakukan oleh pemerintah, pemerintah daerah dan/atau masyarakat. Setiap fasilitas pelayanan kesehatan wajib memberikan akses yang luas bagi kebutuhan penelitian dan pengembangan dibidang kesehatan dan mengirimkan laporan hasil penelitian dan pengembangan kepada pemerintah daerah atau Menteri. Sehingga fasilitas kesehatan saat ini benar-benar sangat dibutuhkan untuk penanganan kasus pasien yang terpapar COVID-19.

Hasil dari pengamatan menunjukan bahwa pasien yang terpapar COVID-19 terus meningkat dan bertambah setiap harinya. Hal ini dikarenakan banyak pasien yang tidak menerapkan perilaku hidup sehat dan tidak mengikuti protokol kesehatan dengan baik dan benar.

Hasil dari pengamatan juga menunjukkan bahwa fasilitas kesehatan yang sudah cukup baik perlu ditingkatkan kembali karena semakin bertambah banyak pasien yang terpapar COVID-19 ini setiap harinya. Pemerintah perlu menambah fasilitas kesehatan dan tenaga medis untuk tempat isolasi dan merawat pasien yang terpapar COVID-19. 


\section{Kesimpulan}

Berdasarkan hasil dari analisis dan data yang diperoleh dapat disimpulkan bahwa meningkatnya pasien yang terpapar COVID-19 ini disebabkan oleh mereka yang tidak menerapkan hidup sehat dan dan tidak menerapkan protokol kesehatan yang telah dibuat oleh Kemenkes RI. Selain itu untuk fasilitas kesehatan yang diberikan saat ini juga masih kurang sehingga pasien yang terpapar COVID-19 banyak yang belum menapatkan perawatan yang baik. Fasilitas kesehatan dan jumlah tenaga medis juga perlu ditingkatkan lagi karena pasien yang terpapar COVID-19 bertambah setiap harinya. 


\section{Daftar pustaka}

Kemkes RI. 2020. Jaga diri dan Keluarga Anda dari Virus Corona-COVID-19. [Online]

Direktorat Kesehatan Lingkungan Dirjen Kesehatan Masyarakat Kementerian Kesehatan RI. (2020).

Panduan Pencegahan Penularan COVID-19 di Tempat dan Fasilitas Umum. Jakarta: Kementerian Kesehatan 
